\title{
The Law and Impact of Political Corruption on Community Trust In Political Parties In Indonesia*
}

\author{
Moh. Ali Wafa, ${ }^{1}$ Sudirman Abbas, ${ }^{2}$ Umar Sulaiman ${ }^{3}$ \\ Universitas Islam Negeri Syarif Hidayatullah Jakarta \\ doi $10.15408 / \mathrm{jch} . v 9 \mathrm{i} 1.20140$
}

\begin{abstract}
This study aims at examining the law and impact of corrupt politician behavior on public trust in political parties and the efforts of reforms by the parties. Using the survey method, this study has come to the following conclusions. (1) the corruption committed by politicians mostly occurs due to the work pattern and the Indonesian political system which develops towards political apathy, in which regeneration does not optimally take place, while the drive to maintain power and dominate the political parties in the state system is increasing; (2) the corruption does not only influence the public trust in political parties, but also the perspective and paradigm of society towards the political system and government in Indonesia. (3) The impact of this political apathy, which we might be able to see from how the radicalism and extremism easily exist and develop in Indonesia. An encouragement to even create a new system is present from this political apathy. If this is not immediately corrected, a change in the system in Indonesia can probably occur.

Keywords: Law; Corruption; Politicians; Political Parties; Community Trust
\end{abstract}

* Received: February 11, 2021, revised: February 18, 2021, accepted: March 18, 2021, Published: April 1, 2021.

${ }^{1}$ Moh. Ali Wafa is a lecturer at the Faculty of Shariah and Law, Universitas Islam Negeri Syarif Hidayatullah Jakarta. JI. Ir. H. Juanda 95 Ciputat, Jakarta 15412. E-mail: m.aliwafa@uinjkt.ac.id

${ }^{2}$ Sudirman Abbas is a lecturer at the Faculty of Shariah and Law, Universitas Islam Negeri Syarif Hidayatullah Jakarta. Jl. Ir. H. Juanda 95 Ciputat, Jakarta 15412. E-mail:

sudirman.abbas@uinjkt.ac.id

${ }^{3}$ Umar Sulaiman is a Graduate School of Syarif Hidayatullah State Islamic University, Jakarta. JI. Ir. H. Juanda 95 Ciputat, Jakarta 15412. E-mail: umar.sulaiman@gmail.com 


\title{
Hukum dan Dampak Korupsi Politik Terhadap Kepercayaan Masyarakat Pada Partai Politik di Indonesia
}

\begin{abstract}
Abstrak
Penelitian ini bertujuan untuk mengkaji hukum dan dampak perilaku politikus korup terhadap kepercayaan publik terhadap partai politik dan upaya reformasi yang dilakukan oleh partai tersebut. Dengan menggunakan metode survei, penelitian ini menghasilkan kesimpulan sebagai berikut. (1) Korupsi yang dilakukan oleh politikus sebagian besar terjadi karena pola kerja dan sistem politik Indonesia yang berkembang ke arah apatisme politik, dimana regenerasi tidak berlangsung secara optimal, sedangkan dorongan untuk mempertahankan kekuasaan dan mendominasi partai politik dalam sistem ketatanegaraan. meningkat; (2) Korupsi tidak hanya mempengaruhi kepercayaan publik terhadap partai politik, tetapi juga cara pandang dan paradigma masyarakat terhadap sistem politik dan pemerintahan di Indonesia. (3) Dampak dari sikap apatis politik ini, yang mungkin dapat kita lihat dari betapa mudahnya radikalisme dan ekstrimisme tumbuh dan berkembang di Indonesia. Dorongan untuk bahkan menciptakan sistem baru hadir dari sikap apatis politik ini. Jika tidak segera diperbaiki, perubahan sistem di Indonesia kemungkinan besar bisa terjadi.

Kata Kunci: Hukum; Korupsi; Politisi; Partai Politik; Kepercayaan Masyarakat

\section{Закон и влияние политической коррупции на доверие общества политическим партиям в Индонезии}

\begin{abstract}
Аннотация
Это исследование направлено на изучение закона и влияния коррумпированного поведения политиков на общественное доверие политическим партиям и усилия партий по проведению реформ. Используя метод опроса, это исследование пришло к следующим выводам: (1) коррупция, совершаемая политиками, в основном происходит из-за модели работы и политической системы Индонезии, которая развивается в сторону политической апатии, при которой возрождение не происходит оптимально, в то время как стремление сохранить власть и доминировать над политическими партиями в государственной системе повышается; (2) коррупция влияет не только на доверие общества политическим партиям, но также на взгляды и парадигму общества в отношении политической системы и правительства в Индонезии; (3) влияние этой политической апатии, которое мы могли бы увидеть по тому, как радикализм и экстремизм легко существуют и развиваются в Индонезии. Эта политическая апатия дает стимул даже к созданию новой системы. Если это немедленно не исправить, вероятно, произойдут изменения в системе в Индонезии.
\end{abstract}

Ключевые слова: Закон; коррупция; политики; политические партии; общественное доверие 


\section{A. INTRODUCTION}

One of the most crucial issues to solve by the nation and the Indonesian government is corruption (Naleni Indra, 2013: 89, Hamid Basyahib, 2012: 2, and Taufik Rinaldi, 2007: 2). The longer such criminal act grows in Indonesia, the more difficult it is to overcome.

The rise of this act in the country allegedly occurs in all fields and sectors of development, especially after the implementation of regional autonomy. According to Law Number 22/1999 concerning the Local Government amended by Law Number 32/2004, corruption allegedly does not only occur at the central level but also at the local level and it even penetrates to the smallest level of government in the regions.

In practice, it has become a tradition (John ST. Quah, 2003: 64), a latent danger that always haunts human life, and a form of crime to be aware of (Axel Dreher and Friedrich Schneider, 2010: 215). It is indeed a "social parasite" (Kartini Kartono, 2001: 79 and Michael Johnston, 2005: 11) endangering and destroying the joints of government structures and becoming the most significant obstacle to their development. In addition, it is considered as a symptom of social instability (social pathology) and lack of functioning of social discipline that brings massive impacts on human life (Dieter Haller and Cris Shore, 2005: 4).

Corruption was very difficult and almost impossible to bring to a stop considering it is influenced by various factors including cultural factors, the intervention of power, political engineering, infidelity among the executive, judiciary and legislative bodies, and the decline of the moral awareness of the perpetrators. It seems to be a blurred portrait to terminate the virus and the chain of corruption in Indonesia.

According to data has been released by the Corruptions Perception Index 2014, Indonesia, Argentina, Djibouti rank 107th of 175 countries in the world with a score of 34 on a scale of 0-100 (0 means very corrupt). Those data states the level of corruption and abuse of corruption to be high and acute which can threaten the country (Wahyudi 2015: 4).

Based on those, the potential for corruption in Indonesia has occurred so massively by involving various groups from the executive, legislative, judicial, political parties, polices, corporations and other private institutions (Benyamin A. Olken, 2007: 200-24 dan Ruth Zshoche, 2011: 12-29). Based on that factual assumptions are supported by the annual report of KPK in the past three years. 
According to the 2015's Corruption Eradication Commission Annual Report, the types of criminal acts of corruption are as follow: 1), Based on the mode, 57 cases including the procurement of goods and services happen; 2), based on the position, 63 cases are found; 3), based on the agency, about 57 cases occur, and 4) Based on the total area, 468 cases are discovered. Overall, the total case of corruption with various types is equal to 645 cases.

Referring to the 2016's annual report, several types of corruption are illustrated in the followings; 1), Based on the mode, 99 cases including the procurement of goods and services are found; 2), Based on the position, 99 cases are met; 3), based on the agency, 99 cases occur. And 4), based on the total area, 99 cases happen. Here, the total case of corruption is about 396 cases.

Carefully traced, the acts of corruption are suspected to occur in several aspects, such as 1), Culture and source of power by Johan Galtung (Al-Chaidar, 1419: 31) referring to Lord Acton's theory "Power tends to corrupt, absolute power corrupts absolutely", (M. Rachmat, 2013: 275); 2), economic aspects (Gulnaz Sharafutdinova, 2010: 147, Marco Pani, 2011: 164, Peter Fleeming and Stelios C. Zyglidopoulos, 2009: 9); 3), Political aspects (Robert Klitgaard, 1988: 11, Michael Johnston, 2005: 12-13, Isaac Ehrlich and Francis T. Liu, 1999: 270). According to experts, the rampant criminal acts of corruption are caused by a patrimonial bureaucracy (Koentjaraningrat, 1998: 15) which allows the authorities to smooth their power. This tendency will give birth to what Jean Baudlirrad calls the "perfect crime", (Mien Rukmini, 2006: 97), with the level of "simulacra of crime" and high "invisibility" symptoms, it will transform into a semiotic institution through fake signs (pseudo sign), false signs, and artificial sign. Such signs (courts, suspects, evidence, witnesses as semiotic elements) are now used to obscure reality and falsify truth and justice, (Yasraf Amir Piliang, 2004: 172).

In addition, other factors such as the phenomenon of "cultural relativism" (Phyllis Dininio and Sah John Kpundeh, 1999: 5) and "cultural gap" by William F. Ogburn (Benoit Godin, 2010: 11), and traditional culture (Frans Magnis- Suseno, 1992: 126) also arise, which consequently leads the existence of corruption to always reproduces from year to year. No wonder if empiricallyfactually it massively occurred in the Soeharto regime (Rajeswary Ampalavanar Brown, 2006: 953-992).

Those who have heavily got involved in the corruption are politicians from major parties including the Democratic Party, Indonesian Democratic Party of Struggle (PDI Perjuangan), The Party of the Functional Groups (Golongan Karya/Golkar), Prosperous Justice Party (Partai Keadilan Sejahtera/PKS), 
United Development Party (Partai Persatuan Pembangunan/PPP), Hanura, and National Democrats (Nasional Demokrat/NASDEM).

According to the existing data, in every major party politician who are suspected or convicted of corruption are about 5-15 people and they are mostly party leaders. The E-KTP (electronic ID card) case has also dragged 37 People's Representative Council members to commit corruption from major parties such as Democrats, PDI Perjuangan, Golkar, Hanura, Nasdem, PKS, National Awakening Party (PKB/Partai Kebangkitan Bangsa), National Mandate Party (Partai Amanat Sosial/PAN), and so on, which indeed are currently waiting for progress made by the Corruption Eradication Commission. This suspicion has led to the emergence of the release of 2017's International Transparency with a $60 \%$ probability which placed the People's Representative Council of Indonesia as the most corrupt institution in Indonesia in 2017.

The tendency of corrupt behaviour committed by politicians certainly has consequences that will affect the voter base. There has been a shifting paradigm over the noble values that become the platform of each party, which in turn can disgrace the ethical values it embraces.

This opinion is in line with Jimly Asshiddiqie's argumentation (2014: 1) stating that political parties are nothing more than political vehicles for a ruling elite group who intends to satisfy their lust for power. Further, the shifting behaviour of politicians who tend to be pragmatic and oriented to subjective and absurd materials seems to have straddled democratic values.

According to Nico Harjanto (2011: 139-140), the existence of political parties has become the conditio sine qua non to function democratic mechanisms. As an organization of citizens who have the same political ideals and aim to be involved in state policy-making and to fill political positions at all levels, political parties are the backbone of democracy. Political parties become a bridge between political owners, namely the people, with the government as the holder of the power mandate.

The existence of political parties that are very central in this democracy certainly cannot be separated from the various very important roles that it carries out in consolidating democracy through the implementation of its functions. This argument, according to the author must be mainstream and platform, so that efforts to ground its functions and roles as a catalyst for democracy become the task of the constitutional struggle.

Furthermore, Nico Harjanto (2011: 140-141) said that political parties that should be able to prepare the best cadres to fill public positions turned out 
to be mostly filled with people who only had the power and closeness to the leadership. Therefore, it is not surprising that human resources in political parties can be said to be of poor quality because meritocracy or the career pathing system is not working as well.

Political parties are also the most ambiguous and problematic democratic institutions. Ambiguous because political parties cannot be fully considered or treated as public institutions or especially as private institutions. Political parties do not get primary funding or facilities and personnel assistance from the state so that their position as public institutions is not strong. On the contrary, political parties cannot be fully regarded as private institutions, as are foundations, cooperatives, or mass media companies because political parties are engaged in the field of power and involve open society.

This lack of clarity affects the arrangement of political parties in general, and in the arrangement of political financing, party financing, campaign financing and accountability of political parties in particular.

The ambiguity-problematic conditions experienced by the aforementioned political parties and politicians are allegedly an entry point to seek funding for the parties and capital to settle them in facing the constituency of legislative elections in the next period. Such phenomenon, indeed, leads to a very resistant consequence among the community towards the politicians and their parties who are involved in corruption and apathy that has appeared through the white group movement, those who are reluctant to vote.

The public perception of political parties after many politicians have been caught red-handed by the Corruption Eradication Commission (KPK) due to corruption. During this time, the existence of political parties has been used as a purse to accommodate money from corruption. At the same time, the parties always deny that their cadres are involved in committing corruption. Since the reform era, almost all political parties in Indonesia have seen their cadres get involved in corrupt practices.

The survey showing the contradictions between expectations and reality indicates that political and state apathies have taken place in our society. This is dangerous considering the community does not only avoid belief but also do not care about the system that takes place in Indonesia anymore

That phenomenon gave rise to community resistance to politicians and their parties involved in criminal through Golput (white group). According to Arbi Sanit (Anton Yuliono, 2013: 180-181), abstentions (Golput) can be classified into three, first, piercing more than one party image. Second, stab the white part 
of the voter letter. Third, do not go to the ballot box with the awareness not to use the right to vote.

Based on the results of Anton Yuliono's research on Anton Yuliono, (2013: 180-181) about the public trust in political parties with the object of research in the city of Surabaya, it was concluded that the community would not have politicians and political parties because they were involved in corruption at $67 \%$. In addition, people generally refuse to use their right to vote because they consider that the legislative elections and regional head elections are merely political routines that benefit political parties and their politicians.

This was also justified by Pramono Anung through his research, which concluded that the political motivation that often settles in the minds of politicians is caused by economic factors (money) and earning a living for his interests, not to fight for the aspirations of the people who have chosen him, an attitude like this, causing many legislative members (DPR) to be pragmatic when carrying out their functions and duties as board members. Thus, the DPR is no longer a place for people with high ideals, nor is it a place for people who want to make laws and those who want to build a better system. Why can this tendency occur? According to the former Secretary-General of the Indonesian Democratic Party of Struggle, because it was caused by an open proportional electoral system that caused high election costs. The results of his research stated that the costs incurred by a legislative candidate to be elected to become a member of the DPR were 2-6 billion Rupiah. There are even candidates whose expenditure reaches 22 billion Rupiah to be elected as members of the DPR (Online News, Corruption: Portrait of Opaque Democracy, March 6, 2013). Thus, based on the number of costs that must be prepared by each candidate for the DPR RI, according to the authors, the tendency to commit corruption is a necessity that must be paid. Therefore, corruption has become an inseparable part of the political system, so that its existence has always been a crucial debate in the context of whether or not corruption can become a basic need in the life of the nation and state. Discourse about corruption is always interesting to observe. This is because its existence is always present and present in the dimensions of human life (Borris Melnikov, 2008: 3).

\section{Literature Review}

Despite a variety of definition of corruption, experts classify several aspects of corruption and its problem. According to Jeremy Pope, Susan RoseAckerman, Maria Dela Rama, and Robert Klittgar, that corruption occurs in 
three forms and meanings, namely; 1) corruption in the lowest sense, acts of betrayal of trust, (2) corruption in the middle level, all acts of abuse of power even though the perpetrators did not get material benefits directly, (3) corruption is the most acute is the abuse of power to gain material benefits that are not their rights (Jeremy Popy, 2003:49).

Based on corruption tendencies that occur more in dimensions and power, according to Bruce Buchan and Lisa Hill, the term corruption contains paradoxical and ambiguous connotations that are always attached to the conception. On the other side, he refers to violations of the law, but on the other hand, carries a moral burden, thus given to a lot of resistance to breaking the chain.

Corruption is not a minor crime or a form of violation of the law alone but is a form of moral disability and carcass failure. Corruption is not just a mistake, but a crime with very dangerous quality. Corruption implies a loss, damage or degeneration. This is the worst form of individual behaviour, corporate mafia or even all countries involved with this problem (Bruce Buchan and Lisa Hill, 2014: 6).

Referring to the various analyzes and opinions of the experts above, a concept can be generalized that corruption, in essence, means abuse, namely abuse. But the general conception of abuse should have clear indicators and parameters so as not to obscure or give birth to misinterpretation, is corruption something negative? Or also has a truth claim that corruption is not always a negative or detrimental thing if viewed from an economic, political, social and cultural and religious perspective. With this position, Michael Jhonston seeks to explain that corruption can be categorized as abuse which directly contradicts other formal rules of law standards. This is considered beneficial because it has the legal power to control strictly and bind. But this understanding has a gap to debate if using empirical postulates and legal standards in which the control function is helpless when facing an authoritarian and repressive cycle of power that attempts to justify systematic errors for power holders (Michael Jhonston, 2005: 18-19), the anomalies, so that other approaches are needed in constructing the concept of corruption abuse.

Artistically divides several typologies or variants of corruption, among others; First, transactive corruption, which is corruption that occurs on the agreement between a donor and recipient for the benefit of both parties. Second, extortive corruption, which involves suppression and coercion to avoid harm to those involved or people who are close to the perpetrators of corruption. Third, investive corruption, which is corruption that starts from an 
offer, as an investment for future profits. Fourth, nepotistic corruption, namely corruption that occurs due to special treatment both in the appointment of public offices and the provision of projects for close families. Fifth, autogenic corruption, namely corruption that occurs when an individual official gains an advantage because of knowing an insider (insider's information) about various public policies that he should keep secret. Sixth, supportive corruption, namely the protection or strengthening of corruption that occurs through the intrigue of power and even violence (Hussein al-Attas,1990:4).

To find out clearly about typology or variants of corruption, the researchers only describe some forms of corruption that are very important for human life, including (a) bribery, (b) gratuity, (c) collusion and nepotism.

\section{B. METHODS}

The research methods in this study apply two instruments, questionnaire and interview. The set of questionnaires, for example, adopts a Likert scale, a scale used to measure a person's attitude towards a subject's attitude. In the meantime, an interview is a data collection method used to obtain information directly from the source.

\section{RESULTS AND DISCUSSION}

The discussion of the results presented in this paper covers the survey result regarding the corruption perception which is divided into five subvariables, (1) Definition of Corruption and its Causes, (2) Government Accountability, (3) Indonesian Politicians, (4) Political Parties, (5) Corruption Handling. Further, the external criteria as the basis of this research refer to Age, Tribe, Occupation, Education and Jakarta Regions.

In term of age, the survey shows $42 \%$ of the respondents are about 20 to 40 years old and $58 \%$ are 40 years old and over. Regarding maturity, the respondents are mature and have sufficient knowledge in making decisions and understanding the research intentions in building perceptions of corruption.

In general, the respondents in this study are dominated by Javanese by $24 \%$, followed by Betawi tribes by $23.4 \%$, Sundanese by $15.2 \%$, Eastern Indonesia consisting of Tribes in Kalimantan, Sulawesi, Maluku to Papua by $13 \%$, Minang by $12.6 \%$, and the tribes in Sumatra such as Aceh, Batak, Palembang which are incorporated into Sumatra by $11.8 \%$. 
Regarding the education level, the respondents are dominated by Diploma and/or undergraduate program by $45.2 \%$, high school alumni by $37.2 \%$. In these two levels of educational backgrounds, the data of research are predominantly collected as the respondents with Master's degree are about $9 \%$, a doctoral program about $3 \%$ and middle school about $7.4 \%$ respectively.

As for the occupation, the average respondents work as a teacher (31\%), employees $(25 \%)$, self-employed $(16.4 \%)$, labour $(15.4 \%)$, students $(7.4 \%)$ and housewives $(4.8 \%)$. If we generalize the results from all regions in Jakarta, we will see the followings: In general, the overall survey results show a higher number of positive items.

The positive items in the survey here are statements indicating general assumptions that develop in theory and concept. In the definition of corruption and its causes, for example, an act of corruption such as embezzlement is adverse action to the economy of the country" and/or "Corruption is an act intended to give profit which is not following the official obligations". In this affirmative statement, respondents generally agree and expect system improvement in Indonesia.

However, when faced with a negative statement illustrating how corruption takes place in Indonesia, the difference found by researchers is only about $1 \%$. They agree to the statement "Saying thank you by giving something for a particular job is a normal thing to do in Indonesia" or "Cutting aid or costs incurred by the government is part of the award that is expected by the Bureaucracy in Indonesia". This shows although they fundamentally understand, realize and know that corruption is dangerous and destructive, at the same time they also feel apathetic as corruption keeps going on.

Regarding the government accountability variables, for example, the scale of the positive items is higher than the negative ones, but with only $2 \%$ to $3 \%$ difference between the positive and the negative points, it is assured even though on the one hand they agree about the positive items and expect this would happen in Indonesia, the respondent also realize that such condition is not that simple. In another word, at the time this research took place, they were in a state of giddiness. The great news is they have confidence that this country is trying to improve itself, and they agree with it although they also realize the fact that corruption is still happening in Indonesia and requires considerable effort to eliminate it. 


\section{CONCLUSIONS}

Based on the survey, this study concludes the followings: (1), corruption committed by the politicians occur due to the work pattern and Indonesian political system that grows towards political apathy, in which regeneration does not optimally take place, while the drive to maintain power and dominate the party in the state system is getting higher. consequently, the political parties do not become a forum to build politicians, but to produce opportunists in the government system; (2), the corruption does not only influence the public's trust in political parties but also the perspective and paradigm of the society towards the political system and government in Indonesia.

\section{REFERENCES}

Arikunto, Suharsimi, 1977. Prosedur Penelitian Suatu Pendekatan Praktek, Jakarta: Rineka Cipta,

Badjuri, Achmad, 2011. "Peranan Komisi Pemberantasan Korupsi (KPK) Sebagai Lembaga Anti Korupsi di Indonesia", Jurnal Bisnis dan Ekonomi, Vol. 18. No. 1

Basyaib, Hamid, et al, 2012. Mencuri Uang Rakyat: 16 Kajian Korupsi di Indonesia, Cet. I; Jakarta: Aksara Foundation

Brown, Rajeswary Ampalavanar, 2006. "Indonesian Corporation, Cronyism and Corruption, Jurnal Modern Asian Studies, Vol. 40, No. 4

Buchan, Bruce dan Lisa Hill, 2014. An Intellectual History of Political Corruption: Political Corruption and Governance, New York: Palgrave Macmillan.

Dininio, Phyillis, dan Sah John Kpundeh, 1999. A Handbook On Fighting Corruption, Washington DC: Center For Democracy and Governance

Dreher, Axel, dan Friedrich Schneider, 2010. "Corruption and The Shadow Economy: An Empirical Analysis" Jurnal Springer Vol. 144 No. 1

Dye, Kelly, 2005 "Maslow, Man Interrupted: Reading Management Theory in Context", Journal Management Decision, Vol. 43, No. 10.

Fromm, Erich, 1964. The Heart of Man: Its Genius for Good and Evil, London: Routledge and Kegan Paul.

Girling, John, Corruption, Capitalism, and Democracy, USA: Routledge Studies In Social And Political Thought, tp, th. 
Godin, Benoit, 2010. “Innovation Without the Word: William F. Ogburn's Contribution to Technological Innovation Studies Project on the Intellectual History of Innovation Working Paper", No. 5

Haller, Dieter, dan Cris Shore (Ed), 2005. Corruption: Anthropological Perspectives, London: Pluto Press.

Hamzah, Andi, 1991. Korupsi di Indonesia Masalah dan Pemecahannya, Cet. I; Jakarta: Gramedia Pustaka Utama.

Hilmy, Masdar,2008. Islam Profetik: Substansiasi Nilai-Nilai Agama di Ruang Publik, Yogyakarta: Kanisius.

Indra, Naleni, 2013 "Permasalahan Korupsi Dan Peran KPK dalam Memberantas Korupsi di Indonesia", Jurnal Ekonomi, Vol 16, No 2.

Jhonston, Michael, 2005. Syndromes of Corruption: Wealth, Power and Democracy, New York: Cambridge University Press

Kartono, Kartini, 2001. Patologi Sosial, Cet. VII; Jakarta: Rajawali Press

Klitgaard, Robert, 2001. Membasmi Korupsi, Cet. Jakarta: Yayasan Obor

Olken, Benyamin A., 2007. "Monitoring Corruption: Evidence from a Field Experiment in Indonesia", Journal of Political Economy, Vol. 115, No. 2,

Rakhmat, M., 2013. Reorientasi Terhadap Hukum Pidana Administrasi dalam Memberantas Korupsi di Era Desentralisasi Fiskal,Cet. I; Bandung: Maulana Media Rafika.

Rinaldi, Taufik, et al, 2007. Memerangi Korupsi di Indonesia yang Terdesentralisasi Studi Kasus Penanganan Korupsi Pemerintah Daerah, Cet. I; Jakarta: Justice for The Poor Project, 2007.

Seeley, Eric Steven, 1988. The Implications of Maslovr's Theory of Motivation for Consumer Behavior: An Hierarchical Consumption Theory, Disertasi, Amerika Serikat: Graduate School of Business Administration New York University.

Thohary Wahyudi, et.al, 2015. Survey Persepsi Korupsi 2015, Jakarta: Tranparency International Indonesia.

Zschoche, Ruth, 2011. "A Multilevel Model of Police Corruption: Anomie, Decoupling, and Moral Disengagement", Disertasi, Florida: University of South Florida. 